\title{
津波により陸上斜面上に形成される 堆積砂分布に関する水理実験
}

\author{
原田＼cjkstart賢治 1 ・高橋 智幸 2 ・野島 和也 3 \\ 1正会員 静岡大学准教授 防災総合センター（†422-8529 静岡県静岡市駿河区大谷836） \\ E-mail: harada.kenji@ shizuoka.ac.jp \\ 2正会員 関西大学教授 社会安全学部（ 569-1098 大阪府高槻市白梅町7-1） \\ E-mail: tomot@kansai-u.ac.jp \\ 3正会員 日本工営株式会社 中央研究所（†300-1259 茨城県つくば市稲荷原2304） \\ E-mail: a7385@n-koei.co.jp
}

\begin{abstract}
津波堆積物の層厚や粒径分布などの情報は，土砂を押し流す津波の水理量との相関が高いと考えられ， 津波堆積物に関する詳細な調査結果からその堆積物を形成した津波外力を推定することが期待される。そ のためには, 津波堆積物の形成メカニズムの理解および津波移動床モデルによる再現性の向上が必要とな る。本研究では，津波により陸上斜面上に形成される堆積砂分布について，砂の粒径，遡上域の勾配，外 力を変化させて津波移動床の水理実験を実施した。その結果，遡上距離と堆積物形成距離との関係，入射 波と堆積物の分布の関係, 砂の粒径の相違による堆積物の分布の相違, 単一砂と混合砂による堆積物の分 布の相違について検討を行った。
\end{abstract}

Key Words : tsunami deposit, particle size, sediment distribution, sand-catcher, hydraulic experiment

\section{1. はじめに}

2011 年東北地方太平洋沖地震津波では，地震および 津波の想定が実際に起こった現象と比べ過小評価であっ た.このような地震および津波の想定が過小評価となっ た原因としては，既往地震および津波に関する知見や情 報が不足していたことが挙げられる．特に，津波は発生 頻度が低いため，歴史津波に関する資料は極めて限られ ている，歴史津波を調べる手法として，津波堆積物が直 接的な物的証拠として有効であるが，津波来襲の有無の 判定にのみ使われていたのがこれまでの実状である.

しかし，津波堆積物の層厚や粒径分布などの情報は， 土砂を押し流寸津波の水理量との相関が高いと考えられ， 津波堆積物に関する詳細な調査結果からその堆積物を形 成した津波外力を推定することが期待される．そのため には, 津波堆積物の形成メカニズムの理解および津波移 動床モデルによる再現性の向上が必要となる.

これまでに, 津波堆積物の形成メカニズムの理解を目 的とした水理実験が，長谷川ら ${ }^{1)}$, 菅原ら ${ }^{2)}$, 原田ら ${ }^{3)}$ により検討されている. 長谷川ら ${ }^{11} は ， 1 / 20$ 勾配の不透 水性一様斜面に津波を想定した孤立波が遡上したときに 豊浦標準砂（中央粒径 $0.293 \mathrm{~mm}$ ）が形成寸る津波堆積物
の分布を計測している．汀線付近では陸側から沖側に向 けての戻り流れの強い流速の影響で堆積物が減少し, 汀 線から離れた遡上範囲では遡上限界に向けて堆積物が 徐々に減少していくくさび状の堆積分布が確認されてい る. 菅原ら ${ }^{2}$ は，1/10 勾配の不透水性一様斜面にゲート 急開による津波段波が遡上したときに粒径の異なる 2 種 類の標準砂（中央粒径 $0.293,0.358 \mathrm{~mm}$ ） が形成する津波 堆積物の分布を計測している. 押し波により $1 / 10$ 斜面 に運ばれた堆積砂分布は，遡上限界に向けて減少するく さび型の分布となり，その後，遡上範囲の斜面に運ばれ た堆積砂は引き波により引き戻され，水路底面と斜面の 接続部付近で引き波の流れが変化する事に影響を受け再 堆積寸る状況が確認されている．また，粒径の小さな砂 がより多くより遠くまで移動している傾向にある事も示 されている.さらに，斜面上で $0.2 \mathrm{~m}$ ごとに計測した流 速から，正と負の流速積分值を求め，押し波による楔型 の堆積分布が正の流速積分值と相関し, 引き波により引 き戻され侵食された砂量分布が負の流速積分值と相関す ることを示している. 原田ら ${ }^{3} k １ / 20$ 勾配の不透水性 一様斜面にゲート急開による津波段波が押し波として遡 上したとき，粒径の異なる 3 種類の砂（中央粒径 0.11, 0.22，0.32mm）が形成する津波堆積砂の分布と移動床初 

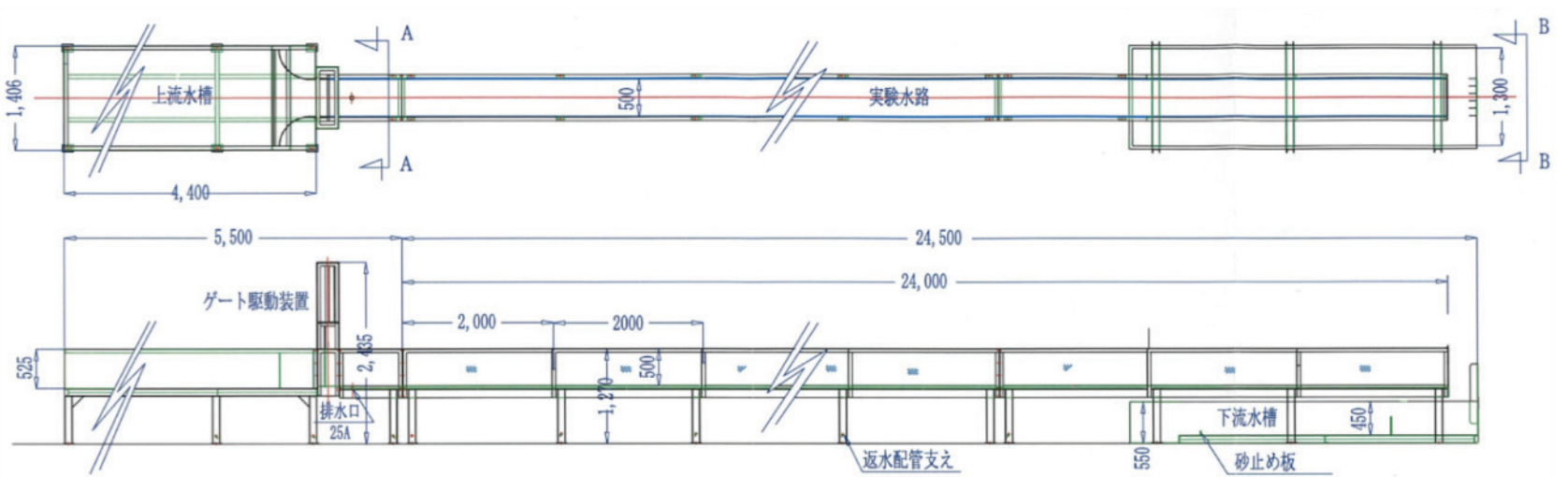

図-1＼cjkstart実験水路の概要

期位置の違い（海域，陸域，海域+陸域）による堆積砂 の分布を計測している．粒径が大きい場合には遡上限界 まで砂が運ばれず斜面下方に多くの砂が堆積し，堆積分 布は急勾配のくさび型となる事を示している．また，粒 径が小さい場合には，遡上限界近くまで砂が運ばれるが， 汀線付近では大きい粒径に比べ少ない堆積量となり, 堆 積分布は緩勾配のくさび形となる事を示している，さら に, 移動床初期位置については, 海域由来の堆積量は少 なく, 陸域由来の堆積量が約 80\%になっていた事を示し ている.これらの様な津波堆積物の形成メカニズムの理 解についての検討が行われているが，単純化された条件 においても十分な理解が行われているとは言えない，さ らに，現象の理解を進めるための再現計算と比較可能な 検証データも十分とは言えない状況である.

これらの様な背景を踏まえ, 本研究では, 砂の粒径, 遡上域の勾配, 外力を変化させた津波移動床の水理実験 を実施し，水理量と津波堆積物の関係を調心゙，[1]遡上 距離と堆積物形成距離との関係, [2]入射波と堆積物の 分布の関係，[3]砂の粒径の相違による堆積物の分布の 相違, [4]単一砂と混合砂による堆積物の分布の相違を 明らかにすることを目的として検討を行った。

\section{2. 水理実験}

\section{(1) 実験装置および実験条件}

実験は水路長 $24 \mathrm{~m}$, 高さ $0.5 \mathrm{~m}$, 幅 $0.5 \mathrm{~m}$ の両側面ガラ 又張り鋼製矩形断面水路を用いて行った. 片側水路端に は, 長さ $4.4 \mathrm{~m}$, 高さ $0.5 \mathrm{~m}$, 幅 $1.4 \mathrm{~m}$ の貯留タンクが接続 しており, 間に幅 $0.5 \mathrm{~m}$, 高さ $0.5 \mathrm{~m}$ の急開ゲートが設置 されている. 図-1 に水路の概要を示寸. 実験では, 貯 留タンクに水を溜め, ゲートを急開寸ることにより津波 を模した長周期段波を造波することができる（図-2）.

実験では，水路内に移動床斜面模型（ゲートより $5 \mathrm{~m}$ の位置, 長さ $2 \mathrm{~m}$, 勾配 1/20） と勾配の異なる 2 種類の 陸上斜面模型（ゲートより $7 \mathrm{~m}$ の位置, 長さ $16 \mathrm{~m}$, 勾配

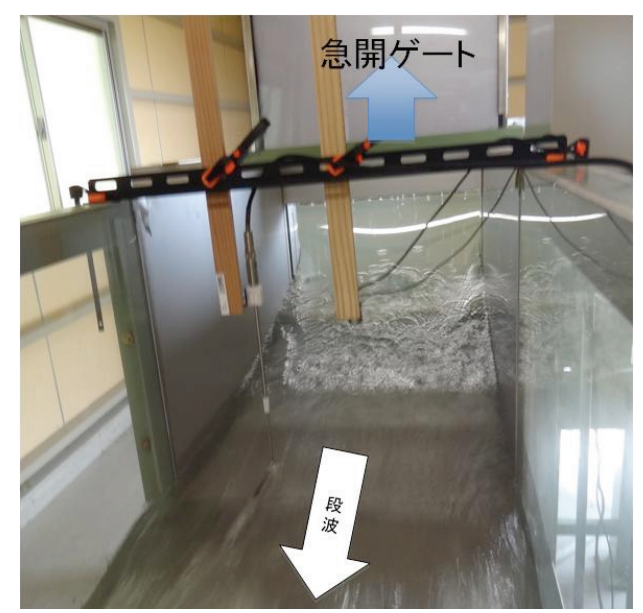

図-2 ゲート急開の状況

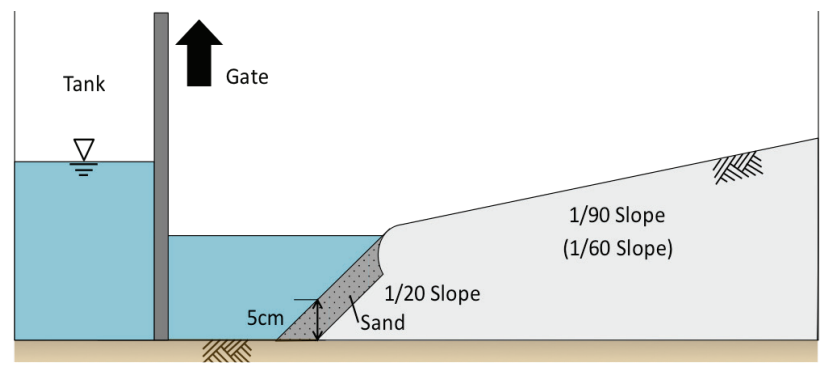

図-3 斜面模型と砂床区間の初期条件

$1 / 90\left(S_{1}\right)$ と $1 / 60\left(S_{2}\right)$ ) を設置し，移動床が水没寸る様に初 期水深 $10 \mathrm{~cm}$ の水を溜めて実験を行った. 斜面模型の表 面には約 $0.2 \mathrm{~mm}$ の粗度を貼り付けている. 移動床斜面 模型は, 図-3 に示寸様に, 厚さ $5 \mathrm{~cm}$ で各粒径の砂を敷 き詰めることができる砂床区間としている.

ゲート急開による入射波は段波条件となる．水路内初 期水深 $10 \mathrm{~cm}$ と貯留タンク水深の水位差 $\Delta H$ を調整する ことにより入射波条件を設定した。陸上斜面勾配 $1 / 90\left(S_{1}\right)$ の時，水位差 $\Delta H$ を $14 \mathrm{~cm}\left(H_{1}\right)$ と $9 \mathrm{~cm}\left(H_{2}\right)$, 陸上斜面 勾配 $1 / 60\left(S_{2}\right)$ の時, 水位差 $\Delta H$ を $19 \mathrm{~cm}\left(H_{1}\right)$ と $14 \mathrm{~cm}\left(H_{2}\right)$ と設 定した。これらの入射波条件は, 各陸上斜面勾配条件に おいて，津波遡上先端が斜面長を超えて越流することの 
表-1 砂の粒径条件

\begin{tabular}{lll}
\hline 粒径\# & 対象粒径 & 粒径 $\left(d_{50}: \mathrm{mm}\right)$ \\
\hline$D_{1}$ & 大 & 0.600 \\
$D_{2}$ & 中 & 0.350 \\
$D_{3}$ & 小 & 0.165 \\
$D_{4}$ & 混合比 1 & 大 $5:$ 中 $3:$ 小 2 \\
$D_{5}$ & 混合比 2 & 大 $2:$ 中 $3:$ 小 5 \\
\hline
\end{tabular}

表-2 実験ケース

\begin{tabular}{llll}
\hline$\#$ & 勾配 & 入射波 $\Delta H(\mathrm{~cm})$ & 粒径 $\left(d_{50}: \mathrm{mm}\right)$ \\
\hline$S_{1}-H_{1}-D_{1}$ & $1 / 90\left(S_{1}\right)$ & $14\left(H_{1}\right)$ & $0.600\left(D_{1}\right)$ \\
$S_{1}-H_{1}-D_{2}$ & & & $0.350\left(D_{2}\right)$ \\
$S_{1}-H_{1}-D_{3}$ & & & $0.165\left(D_{3}\right)$ \\
$S_{1}-H_{1}-D_{4}$ & & & 混合比 $1\left(D_{4}\right)$ \\
$S_{1}-H_{1}-D_{5}$ & & & 混合比 $2\left(D_{5}\right)$ \\
$S_{1}-H_{2}-D_{1}$ & & $9\left(H_{2}\right)$ & $0.600\left(D_{1}\right)$ \\
$S_{1}-H_{2}-D_{2}$ & & & $0.350\left(D_{2}\right)$ \\
$S_{1}-H_{2}-D_{3}$ & & & $0.165\left(D_{3}\right)$ \\
$S_{1}-H_{2}-D_{4}$ & & & 混合比 $1\left(D_{4}\right)$ \\
$S_{1}-H_{2}-D_{5}$ & & & 混合比 $2\left(D_{5}\right)$ \\
$S_{2}-H_{1}-D_{1}$ & $1 / 60\left(S_{2}\right)$ & $19\left(H_{1}\right)$ & $0.600\left(D_{1}\right)$ \\
$S_{2}-H_{1}-D_{2}$ & & & $0.350\left(D_{2}\right)$ \\
$S_{2}-H_{1}-D_{3}$ & & & $0.165\left(D_{3}\right)$ \\
$S_{2}-H_{1}-D_{4}$ & & & 混合比 $1\left(D_{4}\right)$ \\
$S_{2}-H_{1}-D_{5}$ & & & 混合比 $2\left(D_{5}\right)$ \\
$S_{2}-H_{2}-D_{1}$ & & $14\left(H_{2}\right)$ & $0.600\left(D_{1}\right)$ \\
$S_{2}-H_{2}-D_{2}$ & & & $0.350\left(D_{2}\right)$ \\
$S_{2}-H_{2}-D_{3}$ & & & $0.165\left(D_{3}\right)$ \\
$S_{2}-H_{2}-D_{4}$ & & 混合比 $1\left(D_{4}\right)$ \\
$S_{2}-H_{2}-D_{5}$ & & & 混合比 $2\left(D_{5}\right)$ \\
\hline
\end{tabular}

無い条件として設定している.

移動床区間における砂の初期粒径条件の違いによる堆 積砂分布への影響を検討寸るため, 中央粒径の異なる単 一粒径の条件を 3 ケースと混合比の異なる砂の条件を 2 ケースの計 5 ケースを設定した。 用いた砂の粒径条件を 表-1 に示寸. 単一粒径の条件として, 大粒径 $\left(D_{1}\right)$, 中粒径 $\left(D_{2}\right)$ ，小粒径 $\left(D_{3}\right)$ を設定し, 混合砂の条件と して, 粒径の大中小の混合比を大粒径 $\left(D_{1}\right)$ が多い比率 を混合比 1 (大 $5:$ 中 $3:$ 小 2), 小粒径 $\left(D_{3}\right)$ が多い比 率を混合比 2 (大 $2:$ 中 $3:$ 小 5) と変化させて設定した. 以上の実験条件の設定より, 本研究で検討した実験ケ 一スの一覧を表-2に示寸.

\section{(2) 計測項目}

\section{a) 津波の水理条件計測}

実験では津波の水理条件を計測するため, 図-4 に例 を示寸様に計 6 点で水面変動と水平流速を各斜面条件に おいて計測した。水面変動は超音波波高計（OMRON 社 製）を用い，水平流速は電磁流速計（KENEK 社製; [1], [2]）とプロペラ式流速計（中村製作所製；[3]， [4]，[5],

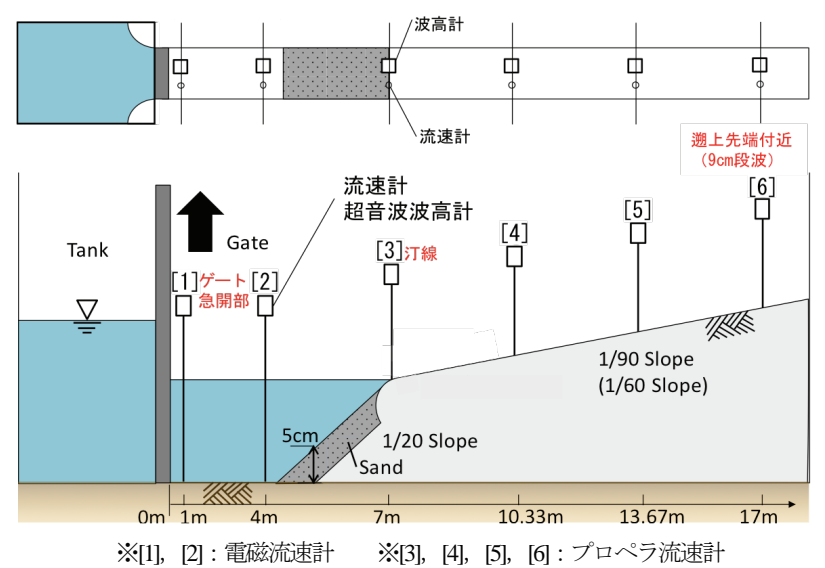

図-4 計測機器設置位置

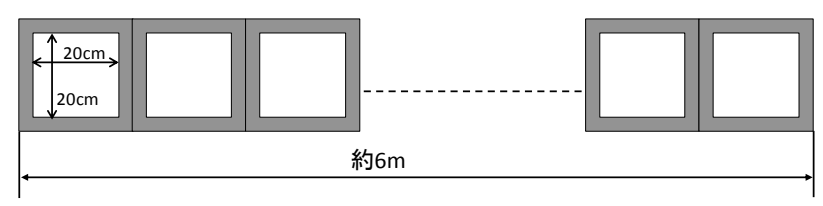

図-5 サンドキャッチャー

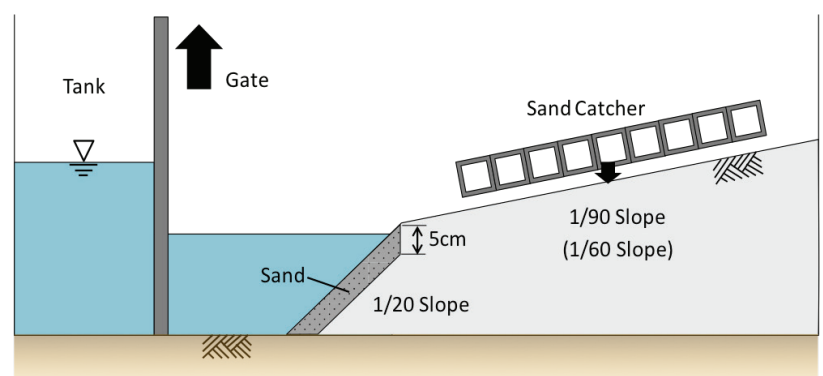

図-6サンドキャッチャーによる砂の捕捉方法

[6]）用いて計測を行った。計測は各斜面条件および各 入射波条件において 3 回行い, 実験の再現性を確認して 代表值を計測值として用いた，全実験ケースで 3 回ずつ 実施した計測から，実験の再現性が良好であることを確 認している.

\section{b) 陸上斜面上の堆積砂分布の計測}

移動床区間を津波段波が通過し，陸上斜面を遡上する ことにより，斜面上に堆積砂が運ばれる．この堆積砂の 分布を定量的に計測するため, サンドキャッチャーを作 成し砂の量の空間分布を計測した. サンドキャッチャー は，図-5 に示寸様に， $20 \mathrm{~cm} \times 20 \mathrm{~cm}$ のマス状の枠を水路 長さ方向に約 $6 \mathrm{~m}$ の長さにつなげた梯子状のものである. 本研究では, 津波段波が斜面遡上し遡上先端部からの 戻り流れによる反射波が形成される前に，サンドキャッ チャーのマスの開口部を水面から陸上斜面の表面に向け て瞬時にかぶせることで，津波段波の水と一緒に運ばれ た掃流砂と浮遊砂の両方を $20 \mathrm{~cm} \times 20 \mathrm{~cm}$ のマスの中に捕 捉することとした（図-6）。なお，サンドキャッチャー の陸上斜面の表面と接寸る部分には，柔軟性のある防水 シール材を取り付け，捕捉された水と砂が各マスから漏 
表-3 サンドキャッチャーによる堆積砂分布計測区間の例

\begin{tabular}{llll}
\hline 勾配 & $\Delta H(\mathrm{~cm})$ & 遡上限界 & 計測区間※ \\
\hline $1 / 90\left(S_{1}\right)$ & $14\left(H_{1}\right)$ & 22.0 & $12.0-18.0$ \\
& $9\left(H_{2}\right)$ & 17.5 & $9.0-15.0$ \\
$1 / 60\left(S_{2}\right)$ & $19\left(H_{1}\right)$ & 22.5 & $12.0-18.0$ \\
& $14\left(H_{2}\right)$ & 19.5 & $9.0-15.0$ \\
\hline
\end{tabular}

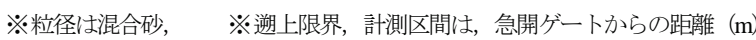

れださない様にした．本研究では，戻り流れの発生前に サンドキャッチャーにより砂を捕捉しており，戻り流れ の影響を考慮していない条件での計測結果となる。これ は，津波が陸上斜面を遡上氾濫した後，一様に海に向か って戻り流れが発生する条件ではなく, 戻り流れが河川 等の局所的に集中する場所から流れ出し，斜面上では強 い戻り流れによる堆積砂への影響が少ない条件に相当し ている．なお，地形勾配が 0.05-0.87\%（1/2000 - 1/115） と 緩やかな仙台平野では，防潮堤等の影響もあり，戻り流 れは貞山堀等の地形的低所から緩やかに流れ出たと考え られている (Abe et al. ${ }^{4)}$ ，藤原 ${ }^{5)}$ )。

サンドキャッチャーは，斜面勾配条件と入射波条件に より決まる遡上限界付近の位置で，堆積砂を捕捉できる 様に設置位置を調整し，表-3 の様に計測区間を設定し た．津波段波の遡上限界位置では，水は到達していても 粒径の条件により砂の移動が確認できない実験ケースも あったため, 砂の移動が確認できた位置でサンドキャッ チャーを設置し計測している.

サンドキャッチャーで捕捉した各マスの中の砂は，水 と一緒に吸引機を用いて個別に吸い出して回収し，砂と 水を分離した後, 砂を炉乾燥させて乾燥質量を電子天秝 で計測した．各マスの乾燥質量から，陸上斜面上の堆積 砂量分布を求めた。ささらに, 混合砂の実験ケースでは, 混合比による堆積砂の分布への影響を検討寸るため，各 マスで回収した砂を炉乾燥させて質量を計測するととも に，ふるい試験により粒度分析を行った。

\section{3. 実験結果}

\section{（1） 水位, 流速の計測結果の例}

図-7，8 に各計測地点で計測された，水位，流速の計 測結果の例を示寸．図-7 は勾配 $1 / 90$, 入射波の $14 \mathrm{~cm}$ の 時 $\left(S_{1}-H_{1}\right)$ ，図-8 は勾配 $1 / 60$, 入射波の $14 \mathrm{~cm}$ の時 $\left(S_{2}\right.$ $\mathrm{H}_{2}$ ）の各計測位置での水位と流速の時系列変化である. 陸上斜面上の計測点の水位上昇量は，浸水深に相当する. 水位変化は，ゲート付近から汀線まで段波先端部で 0.1 から $0.15 \mathrm{~m}$ の急激な水位上昇の変動が見られるが，斜面 上を遡上寸るに従い先端部においても時系列変化が緩や かな水位上昇の変動となっており，陸上斜面上に広がる 津波の遡上過程が計測結果として表れている. 流速は, 段波先端部で急激な速度上昇が発生しており，時間経過
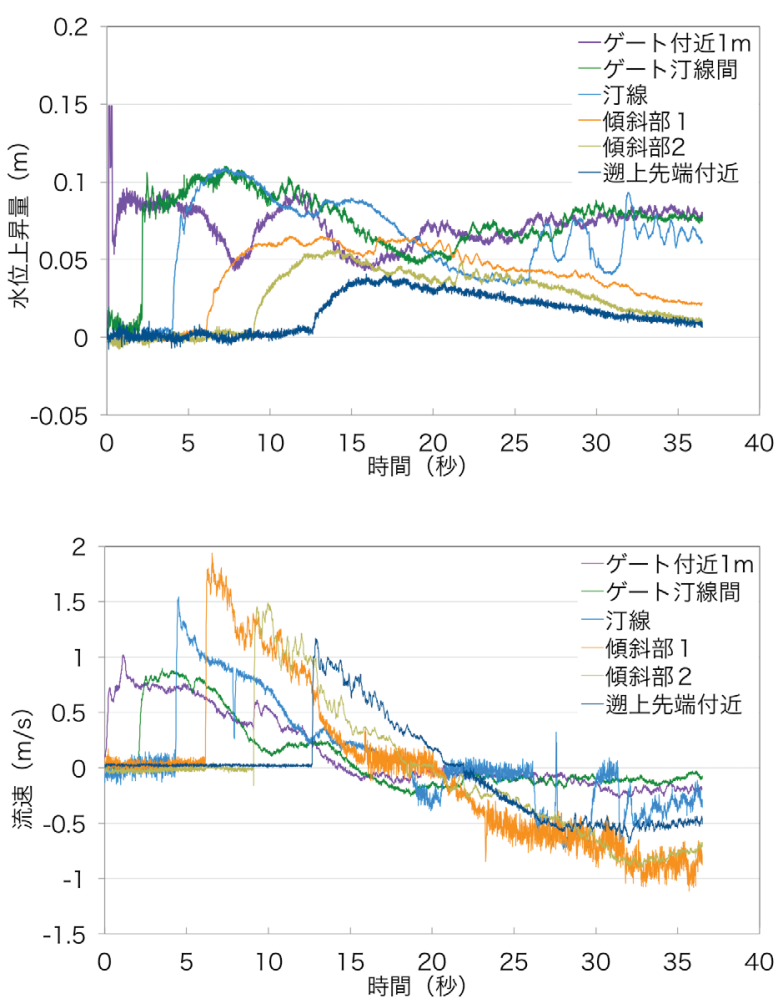

図-7 水位，流速の計測結果例 (勾配 1/90 $\left(S_{1}\right)$ ，入射波 $14 \mathrm{~cm}\left(H_{1}\right)$ )
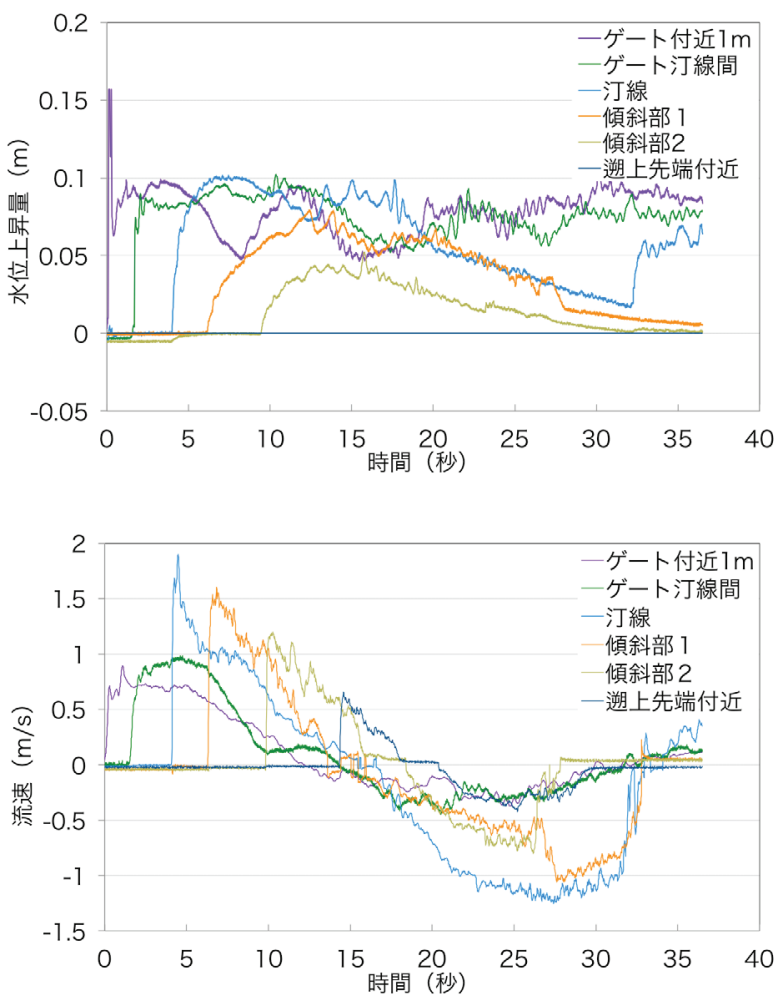

図-8 水位，流速の計測結果例 (勾配 1/60 $\left(S_{2}\right) ， 入$ 射波 $14 \mathrm{~cm}\left(H_{2}\right)$ )

とともに順次，流速が低下している．汀線に近い所では， 段波先端部の押し波で最大 1.5 から $2.0 \mathrm{~m} / \mathrm{s}$ 程度の速い流 
表-4 遡上範囲と堆積砂の到達範囲

\begin{tabular}{|c|c|c|c|c|}
\hline$\#$ & 対象粒径 & 遡上※ & 砂到達※ & 砂到達率※ \\
\hline$S_{1}-H_{1}-D_{1}$ & 大 & 15.0 & 10.0 & 0.67 \\
\hline$S_{1}-H_{1}-D_{2}$ & 中 & & 12.0 & 0.80 \\
\hline$S_{1}-H_{1}-D_{3}$ & 小 & & 15.0 & 1.0 \\
\hline$S_{1}-H_{1}-D_{4}$ & 混合比 1 & & 15.0 & 1.0 \\
\hline$S_{1}-H_{1}-D_{5}$ & 混合比 2 & & 15.0 & 1.0 \\
\hline$S_{1}-H_{2}-D_{1}$ & 大 & 10.5 & 7.8 & 0.74 \\
\hline$S_{1}-H_{2}-D_{2}$ & 中 & & 9.0 & 0.86 \\
\hline$S_{1}-H_{2}-D_{3}$ & 小 & & 10.5 & 1.0 \\
\hline$S_{1}-H_{2}-D_{4}$ & 混合比 1 & & 10.5 & 1.0 \\
\hline$S_{1}-H_{2}-D_{5}$ & 混合比 2 & & 10.5 & 1.0 \\
\hline$S_{2}-H_{1}-D_{1}$ & 大 & 15.5 & 12.0 & 0.77 \\
\hline$S_{2}-H_{1}-D_{2}$ & 中 & & 13.0 & 0.84 \\
\hline$S_{2}-H_{1}-D_{3}$ & 小 & & 15.0 & 0.97 \\
\hline$S_{2}-H_{1}-D_{4}$ & 混合比 1 & & 15.0 & 0.97 \\
\hline$S_{2}-H_{1}-D_{5}$ & 混合比 2 & & 15.0 & 0.97 \\
\hline$S_{2}-H_{2}-D_{1}$ & 大 & 12.5 & 10.2 & 0.82 \\
\hline $\mathrm{S}_{2}-\mathrm{H}_{2}-\mathrm{D}_{2}$ & 中 & & 10.5 & 0.84 \\
\hline $\mathrm{S}_{2}-\mathrm{H}_{2}-\mathrm{D}_{3}$ & 小 & & 12.0 & 0.96 \\
\hline $\mathrm{S}_{2}-\mathrm{H}_{2}-\mathrm{D}_{4}$ & 混合比 1 & & 12.0 & 0.96 \\
\hline $\mathrm{S}_{2}-\mathrm{H}_{2}-\mathrm{D}_{5}$ & 混合比 2 & & 12.0 & 0.96 \\
\hline
\end{tabular}

速值の流れが発生しており，戻り流れも勾配 1/60 では 汀線において最大 $1.0 \mathrm{~m} / \mathrm{s}$ を越える早い流速值の流れが長 時間継続することが確認できる，時系列変化では，斜面 勾配の大きな $1 / 60$ の斜面上において若干短い水位と流 速の変動が見られる.これらの水位と流速の特徴が, 斜 面上の場所により, 計測值の大小, 時間の長短の違いと して計測されている.

\section{（2）遡上範囲と堆積砂の到達範囲}

表-4 に各実験ケースにおける津波段波の遡上範囲と 砂の到達範囲の結果および砂の到達率を示寸，砂の到達 率は, 汀線からの遡上範囲に対する砂の到達した範囲と して算出した. 砂の到達した範囲は, 微量の砂量であっ ても実験で計測できた範囲を用いた。

津波堆積物は一般的に津波の遡上限界範囲よりも狭い 範囲に形成されると知られている（例えば，菅原 $\left.{ }^{6}\right)$ ）。 東北地方太平洋沖地震津波による仙台平野では, 浸水遡 上距離が海岸線から $2.5 \mathrm{~km}$ よりも短い場所では厚さ $0.5 \mathrm{~cm}$ 以上の砂質津波堆積物は約 $90 \%$ 以上の範囲で確認 されており，全ての調查測線で微量の砂質もしくは泥質 の津波堆積物が遡上範囲の $92-99 \% の$ 範囲で見つかって いる $\left(\right.$ Abe et $\left.a l^{4}{ }^{4}\right)$ ）. また，浸水遡上距離が海岸線から 2.71 4.85km の場所では, 厚さ $0.5 \mathrm{~cm}$ 以上の砂質津波堆 積物は遡上距離の $57-76 \%$ の範囲で見つかっている

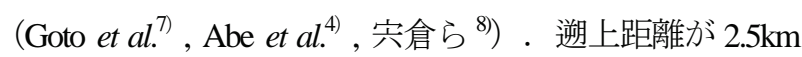
を超える長い場所では，遡上範囲と砂質津波堆積物の到 達範囲の間の差異が大きくなる傾向が示されている.

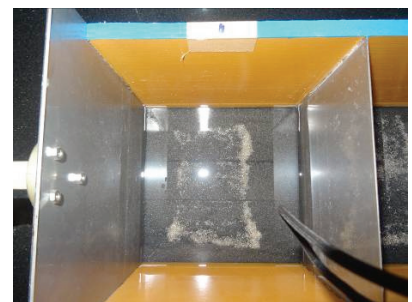

No.20

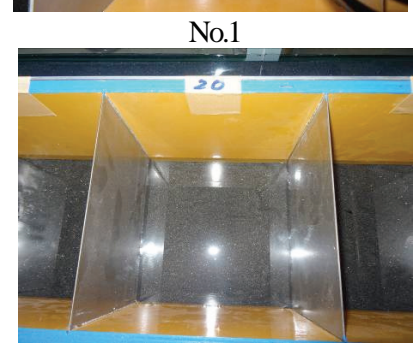

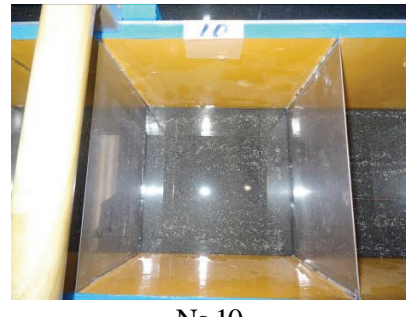

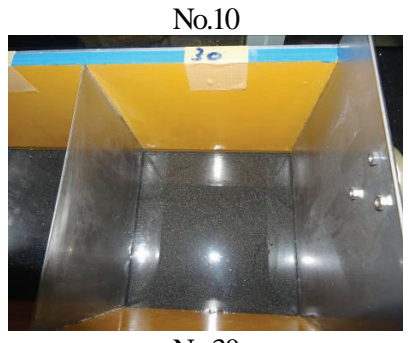

No.30
勾配 $1 / 90$ ，入射波 $14 \mathrm{~cm}$ ，大粒径 $\left(D_{1}\right) \quad\left(S_{1}-H_{1}-D_{1}\right)$ の状況

図-9 サンドキャッチャーによる堆積砂の捕捉状況の例

本研究における遡上範囲と堆積砂の到達範囲に関寸る 実験結果は，現地で観測される津波堆積物の持つ特徵と 同様の結果が得られたことになる. 本研究の結果より, 砂の粒径が大きい場合には砂到達率は小さくなり, 粒径 が小さい場合には到達率が高くなる傾向にあることがわ かる（表-4）。これは，津波の遡上限界付近では，津波 の流速が低下しており, 砂粒子に作用する流体力が小さ く，粒径の大きい砂を多く移動させることができなくな っているためと考えられる.また，同じ入射波条件 $\left(\Delta H\right.$ が $14 \mathrm{~cm}$ の $S_{1}-H_{1}$ と $\left.S_{1}-H_{2}\right)$ に対しては, 斜面勾配が 緩やかな場合 $\left(S_{1}, 1 / 90\right)$ の対象粒径の大小を比較すると 距離で $5.0 \mathrm{~m}$, 砂到達率で 0.33 の変動があるのに対して, 勾配が急な場合 $\left(S_{2}, 1 / 60\right)$ の対象粒径の大小を比較する と距離で $1.8 \mathrm{~m}$, 砂到達率で 0.14 の変動となり, 勾配が 緩やかな方が大きな変動幅となり, 浸水範囲と堆積物の 範囲に差異が大きくなる結果となった。 また，混合砂と 小粒径 $\left(D_{3}\right)$ の砂到達範囲は同じ值となっており, 細か な砂の到達範囲により，混合砂における砂の到達範囲が おおよそ決まると推測できる.

\section{（3）陸上斜面上の堆積砂}

\section{a) サンドキャッチャーによる堆積砂の捕捉状況}

図-9 にサンドキャッチャーにより捕捉された堆積砂 の状況の例 $\left(S_{1}-H_{1}-D_{1}\right.$ : 勾配 $1 / 90$, 入射波 $14 \mathrm{~cm}$, 大粒 径）を示す。図中の番号（No.）はサンドキャッチャー のマスの番号であり, No.1 が最も汀線に近いマスであ り, No.30 が最も遡上限界に近いマスとなる. No.1のマ スの中央付近にサンドキャッチャーに捕捉された堆積砂 を確認することができる．No.30 のマスでは，砂がほと んど到達していない状況であることがわかる。このよう に，サンドキャッチャーにより捕捉した砂をマスごとに 回収し, 炬乾燥させて乾燥質量の計測を行い, 斜面上の 


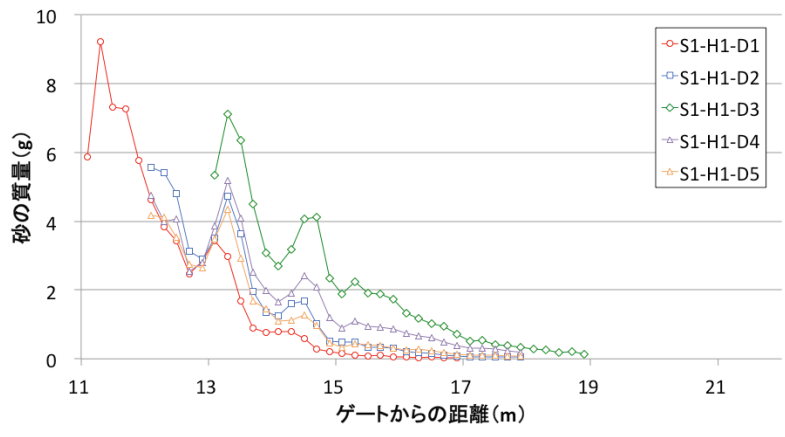

図-10 斜面上の堆積砂量の分布 $\left(S_{1}-H_{1}\right)$

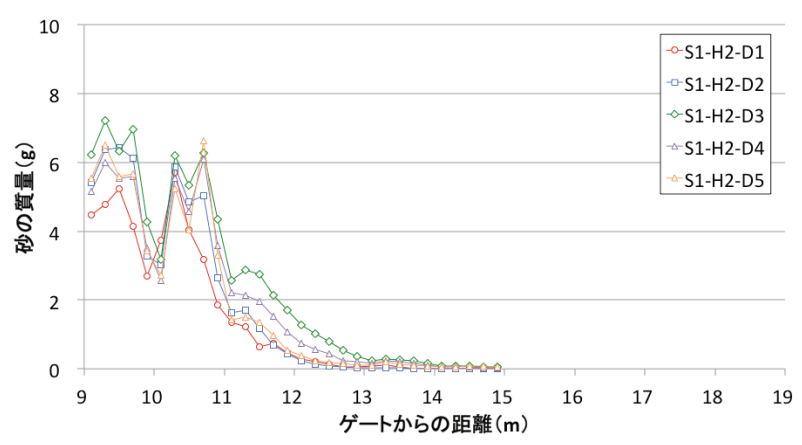

図-11 斜面上の堆積砂量の分布 $\left(S_{1}-H_{2}\right)$

堆積砂量の空間分布を求めた.

\section{b) 堆積砂量分布}

図-10 から図-13 に斜面上で計測された堆積砂量の分 布を示す。図-10 は斜面勾配 $1 / 90$, 入射波 $\Delta H$ が $14 \mathrm{~cm}$ の 時 $\left(S_{1}-H_{1}\right)$ ，図-11 は斜面勾配 $1 / 90$, 入射波 $\Delta H$ が $9 \mathrm{~cm}$ の時 $\left(S_{1}-H_{2}\right)$ ，図-12 は斜面勾配 $1 / 60$, 入射波 $\Delta H$ が $19 \mathrm{~cm}$ の時 $\left(S_{2}-H_{1}\right)$, 図-13 は斜面勾配 $1 / 60$, 入射波 $\Delta H$ が $14 \mathrm{~cm}$ の時 $\left(S_{2}-H_{2}\right)$ の各粒径条件の計測結果である. 各実験ケースにおいて 3 回づつ計測した結果の平均值を プロットしている.

各図より，遡上限界範囲に向からように堆積砂量の分 布はくさび形の減少をして行く状況が確認できる.この 結果は, 現地の津波堆積物や既往実験研究の成果 1), 2),3) とも一致しており，計測位置や分布量などにより違いは あるが全ての分布計測結果でも同様の傾向が確認できる 津波の押し波により運ばれる土砂が，遡上先端に向かう 津波の流速低下に伴い斜面途中から遡上先端に向けて堆 積砂量が減少している状況が計測されている.

また, 単一粒径の結果を見ると, 小粒径 $\left(D_{3}\right)$ の堆積 砂量分布が最も大きい值の分布をとっており, 次いで中 粒径 $\left(D_{2}\right)$ ， 大粒径 $\left(D_{1}\right)$ と堆積砂量が少なくなってい る.この傾向は，原田ら ${ }^{3)}$ の実験結果にも見られる. 同 じ斜面勾配条件，同じ入射波条件の時には，津波が土砂 を押し流とうとする力は同じ様に作用するが，流される 粒径が異なることにより, 流されや寸さ（移動限界の流 速や土砂移動量）に違いが生じるため, 結果としての堆

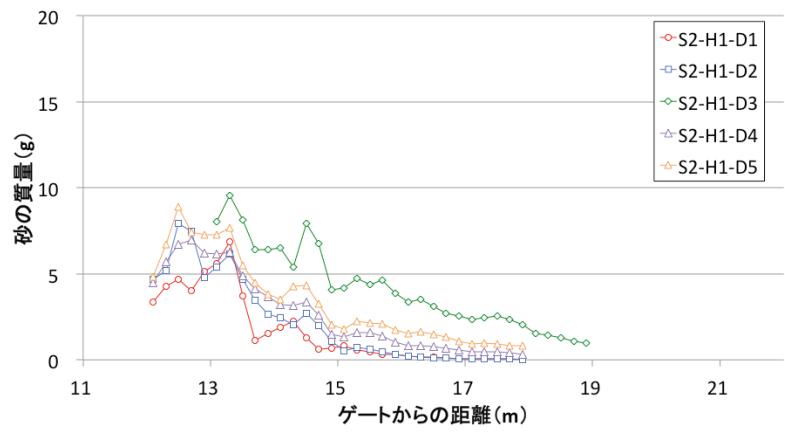

図-12 斜面上の堆積砂量の分布 $\left(S_{2}-H_{1}\right)$

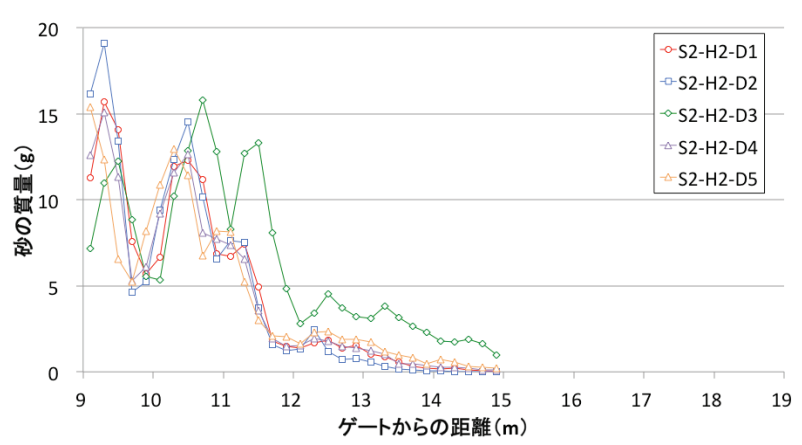

図-13 斜面上の堆積砂量の分布 $\left(S_{2}-H_{2}\right)$

積砂量の分布に違いが出ていると考えられる．また，混 合砂のケース（混合比 $1\left(D_{4}\right)$, 混合比 $2\left(D_{5}\right)$ ) を見 ると, 大粒径 $\left(D_{1}\right)$ と小粒径 $\left(D_{3}\right)$ の堆積砂分布の間に 分布をとることが分かる. 混合比 1 の大粒径が 5 割を占 めるケースでは, 単一粒径の大粒径 $\left(D_{1}\right)$ の結果と比心゙ ると, より多い堆積砂量分布となっている. 同様に, 混 合比 2 の小粒径 $\left(D_{3}\right)$ が 5 割を占めるケースでは, 単 一粒径の小粒径 $\left(D_{3}\right)$ の結果と比べると, より少ない堆 積砂量分布となっている. これらの結果から, 津波堆積 物の供給源となる土砂の粒径の条件により，陸上に形成 される津波堆積物の分布は影響を受け, 中央粒径だけで なく粒度分布によっても堆積砂の分布に影響があること が確認された。

\section{c) 混合砂条件における粒径別堆積砂量分布}

混合砂の実験ケースにおいて，サンドキャッチャーで 捕捉した砂の質量分布と質量比分布の例を図-14 図-17 に示寸. 図-14 は斜面勾配 $1 / 90$, 入射波 $14 \mathrm{~cm}$, 混合比 1 （大 5 : 中 $3:$ 小 2) の時の堆積砂量の粒径別質量分布, 図-15 はこの時の堆積砂量の粒径別質量比率分布の結果 である. 同様に, 図-16 は混合比 2 (大 $2:$ 中 $3:$ 小 5) の時の堆積砂量の粒径別質量分布, 図-17 は粒径別質量 比率分布の結果である. サンドキャッチャーにより回収 された各マスの砂をふるいにかけ，粒径別質量分布を計 測した. 粒度分析の条件として, $0.425 \mathrm{~mm}$ と $0.212 \mathrm{~mm}$ の ふるいを用い, 各ふるいに残った質量と通過した質量を 計測し, 粒径大 $(d>0.425)$, 粒径中 $(0.425<d<0.425)$, 


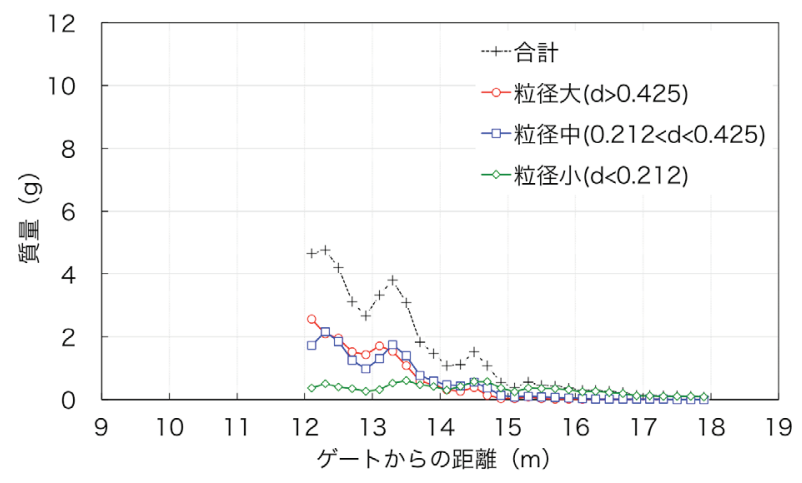

図-14 混合砂における堆積砂量の粒径別質量分布 (勾配 $1 / 90$ ，入射波 $14 \mathrm{~cm}$ ，混合比 1 （大 5 : 中 3 : 小 2) )

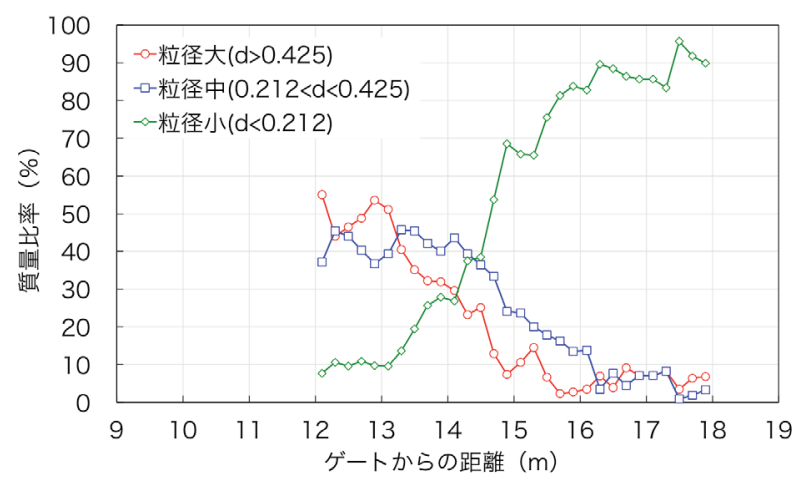

図-15 混合砂における堆積砂量の粒径別質量比率分布 （勾配 $1 / 90$ ，入射波 $14 \mathrm{~cm}$ ，混合比 1 （大 $5:$ 中 $3:$ 小 2$)$ )

粒径小 $(d<0.212)$ の粒径別の砂の質量とした. なお, 粒径別質量分布の計測は, 3 回の平均值では無く, 代表 值として 1 回の計測で得られた砂を用いてふるいにかけ た結果である。

図-14〜17 より, 混合比 1（大 5: 中 3: 小 2) と混合 比 2 (大 $2:$ 中 $3:$ 小 5) の混合砂の堆積砂量合計の分布 は多少の凹凸の差異があるが同程度の量の分布傾向とな っており，その構成を粒径別に見ると粒径大 $(d>$ $0.425)$ と粒径小 $(d<0.212)$ について傾向が大きく異な っていることがわかる. 粒径大 $(d>0.425)$ の分布は, 混合比 1 (大 5 : 中 $3:$ 小 2) においては 12〜14mにかけ て多く，比率分布でも50\%に及んでいるが，混合比 2 （大 2：中 3: 小 5) においては分布量が少なく, $12 \mathrm{~m}$ で 28\%程度の比率が最大となっている. 粒径中（0.212< $d<0.425 ）$ の分布は, 混合比 1,2 ともに質量分布, 質量 比率分布が類似した傾向となっており, 中粒径 $\left(D_{2}\right)$ の 混合の割合が 3 割と同じであることを考えると妥当な結 果と考えられる. 粒径小 $(d<0.212)$ の分布は, 計測区 間全体で広く計測されており，特に遡上限界付近では 90\%を超える割合で粒径小 $(d<0.212)$ が分布している. また, 混合比 1 と混合比 2 を比べると混合比 2 (大 2 : 中 $3:$ 小 5) で多く分布しており, 比率分布も混合比 2

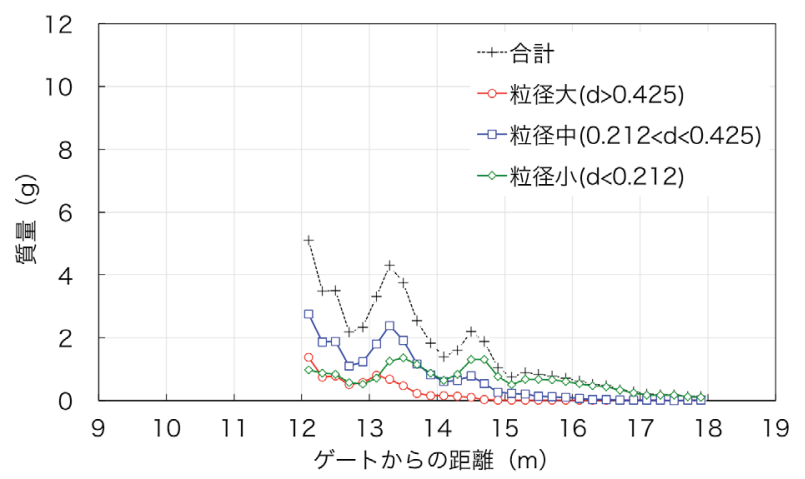

図-16 混合砂における堆積砂量の粒径別質量分布 （勾配 $1 / 90$, 入射波 $14 \mathrm{~cm}$, 混合比 2 （大 $2:$ 中 $3:$ 小 5 ）

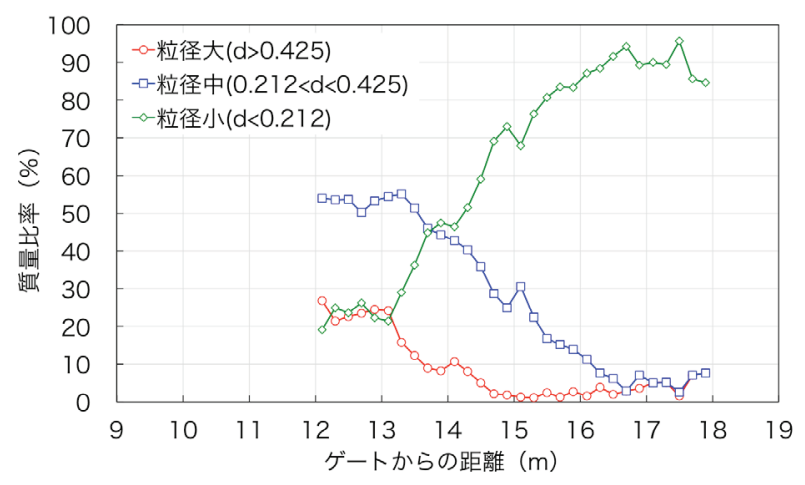

図-17 混合砂における堆積砂量の粒径別質量比率分布 (勾配 $1 / 90$, 入射波 $14 \mathrm{~cm}$, 混合比 2 （大 2 : 中 $3:$ 小 5) )

が大きな割合を示している.

これらの結果から, 混合比の異なる条件で形成された 堆積砂の分布は, 同じ条件の津波で堆積砂量合計では同 程度の分布になったが，堆積砂を構成している粒径分布 に大きな違いが確認された。 このことは, 津波堆積物が 同程度の厚さを持つ場合でも，堆積砂の粒径構成比率と 供給源の粒径分布の特徵から来襲した津波の特徵を検討 できる可能性があることを示していると考えられる.

\section{4. おわりに}

本研究では, 津波により陸上斜面上に形成される堆積 砂分布について, 砂の粒径, 遡上域の勾配, 外力を変化 させて津波移動床の水理実験を実施した. その結果, [1]遡上距離と堆積物形成距離との関係, [2]入射波と堆 積物の分布の関係, [3]砂の粒径の相違による堆積物の 分布の相違, [4]単一砂と混合砂による堆積物の分布の 相違について検討を行った.

本研究の結果より, 津波堆積物が遡上距離よりも狭い 範囲に形成される状況を, 条件を変えて実験的に再現す る事ができた．同じ斜面，津波入射条件でも，津波堆積 物の供給源となる移動床の粒径条件により砂到達率が 
0.67 から 1.0 と大きく変化した. 大粒径時には砂到達率 は小さくなり，小粒径が小さい時には砂到達率が高くな る傾向が確認された。津波堆積物により過去の津波浸水 範囲を検討する際に，堆積物の分布だけでなく，津波堆 積物の供給源の粒径条件も考慮する必要がある事を示唆 している.さらに, 堆積砂量の分布も, 堆積物供給源の 粒径により大きく分布が異なる. これは, 現地で津波堆 積物が厚さを持って見つかったとしても，粒径等でも堆 積する厚さが変化するため, 堆積物の厚さだけから津波 の規模を推定することは難しい事を意味している．また， 堆積物供給源の粒径混合比を変えた実験結果より，同程 度の堆積物厚でも，堆積物を構成する粒径分布の特徴が 異なれば，異なる来襲津波の特徴を持つ可能性がある. これらは今後の津波堆積物の利用において一定の有益な 情報を提供するものと考えられるが，津波堆積物の形成 メカニズムを理解するためには更なる実験や津波土砂移 動数值解析による検討が必要である.

なお，本研究では，押し波により運ばれてくる堆積砂 を対象に水理実験を行っており，地形の勾配や河川等の 影響により，強い引き波が発生しない条件における津波 堆積物の形成過程に関する現象に対応していることにな る. 実際の津波の来襲状況を考えると引き波により土砂 が運び去られることもある.今後，引き波の影響を考慮 した場合において，斜面上に形成される津波堆積物の特 徵と砂の粒径や遡上域の勾配，外力の関係性を明らかに する必要がある。さらに，単純な一様勾配だけでない条 件での検討も実際に津波堆積物が形成する過程を理解す る上では必要になると考えられ，今後の検討課題である.
謝辞：本研究は，原子力規制庁委託事業（代表 : 関西大 学 高橋智幸, 課題名: 津波堆積物に基づく津波波源推 定手法の開発）の成果の一部である.

\section{参考文献}

1）長谷川史郎, 高橋智幸, 上畑義之：津波遡上に伴う 陸域での堆積物形成に関する水理実験, 海岸工学論 文集，第 48 巻, pp. 311-315, 2001.

2) 菅原正宏, 大窪慈生, 菅原大助, 箕浦幸治, 今村文 彦：津波により一様斜面上を移動する土砂および津 波石に関する水理実験, 海岸工学論文集, 第 50 巻, pp. 266-270, 2003.

3) 原田賢治, 今井健太郎, Tran The Anh, 藤木悦史 : 津 波斜面上による陸域での堆積砂形成に関する水理実 験，土木学会論文集 B2（海岸工学），Vol. 67, No. 2, pp.I_251-I_255, 2011.

4) Abe, T., Goto, T. and Sugawara, D.: Relationship between the maximum extent of tsunami sand and the inundation limit of the 2011 Tohoku-oki tsunami on the Sendai Plain, Japan, Sedimentary Geology, Vol. 282, pp. 142-150, 2012.

5) 藤原治: 津波堆積物の科学, pp. 55-56, 東京大学出版 会, 2015.

6) 菅原大助：津波堆積物と津波の規模について, 地学 雑誌, Vol. 23, No. 6, pp. 797-812, 2014.

7) Goto, K., Chagué-Goff, C., Fujino, S., Goff, J., Jaffe, B., Nishimura, Y., Richmond, B., Sugawara, D., Szczuciński, W., Tappin, D. R., Witter, R. and Yulianto, E.: New insights of tsunami hazard from the 2011 Tohoku-oki event, Marine Geology, Vol. 290, pp. 46-50, 2011.

8）宾倉正展, 藤原治, 澤井祐紀, 行谷佑一, 谷川晃一 郎：2011 年東北地方太平洋沖地震による津波堆積物 の仙台 - 石巻平野における分布限界, 活断層 - 古地 震研究報告, No. 12, pp. 45-61, 2012.

(2016. 11. 4 受付, 2017.1.28 修正, 2017.2.18 受理)

\title{
HYDRAULIC EXPERIMENT FOR DISTRIBUTION OF SAND DEPOSIT FORMED ON SLOPE BY TSUNAMI
}

\author{
Kenji HARADA, Tomoyuki TAKAHASHI and Kazuya NOJIMA
}

\begin{abstract}
In the present study, a hydraulic experiment with moving bed was carried out in order to investigate the influence of particle size of sand, slope of run-up areas, and tsunami conditions, to distributions of sand deposited on land slopes by tsunamis. Then, the following matters were examined by using experimental data; the relationship between the run-up distance and deposit formation distance, the relationship of the distribution of the sediment and the incident wave, the difference in the distribution of the deposit due to the difference in particle size of the source sand, the distribution of the deposit by uniform sand and mixed sand. From experiment results, it is shown that the ratio of deposit formation distance and tsunami run-up distance is influenced 0.67 to 1.0 by particle size of sand. This ratio is also changed by slope condition and tsunami wave settings. And the mass distribution of deposit is changed by the particle size of source sand. When utilizing tsunami deposits, it is necessary to consider not only layer thickness but also particle size.
\end{abstract}

